\title{
Southern Tapanuli Society Perception of Pulmonary TB Health and Diseases
}

\author{
Ismail Fahmi ${ }^{1}$, Badaruddin ${ }^{2}$, R. Kintoko Rochadi ${ }^{3}$, Rahayu Lubis ${ }^{4}$ \\ 1 Student of the Public Health Science Doctoral Program, University of North Sumatra \\ 2 Lecturer at the Faculty of Social and Political Sciences, University of North Sumatra \\ 3 Lecturer in the Faculty of Public Health, University of North Sumatra \\ 4 Lecturer at the Faculty of Public Health, University of North Sumatra \\ jaya_barito@yahoo.com
}

\begin{abstract}
Community empowerment programs to tackle pulmonary TB have never been implemented in South Tapanuli Regency, North Sumatra Province, Indonesia. Difficulties in designing interventions related to the socio-cultural community are one of the reasons. This study aims to understand people's perceptions of pulmonary TB health and disease and understand how the community prevents pulmonary TB. Qualitative research was carried out through focus group discussions and in-depth interviews. Participants were chosen purposively based on socioeconomic status, community / religious / adat leaders, and community health center officials, and government health officials. Data were analyzed using content analysis. The results of the analysis summarize the eight categories of statements that most often appear, namely: (1) Pulmonary TB is a dangerous disease; (2) the causes of pulmonary TB disease; (3) stigma related to pulmonary TB; (4) pulmonary TB treatment; (5) prevention of pulmonary TB; (6) information sources; (7) the role of community / religious / adat leaders; and (8) community action patterns. These eight categories are grouped into three domain structures, namely: (1) people's perception of pulmonary TB disease; (2) how to prevent pulmonary $T B$; and (3) health promotion strategies. The theme of deliberation, consensus, cooperation, and harmony that is identical to Dalihan Na Tolu's philosophy emerged as the perception of the people of South Tapanuli towards pulmonary TB disease.
\end{abstract}

Keywords : health perception; Pulmonary TB; dalihan na tolu; content analysis; community empowerment

\section{Introduction}

Tuberculosis or pulmonary TB is still a major global health problem. Pulmonary TB disease has a great effect on the quality of human resources, because it affects the quality and productivity of sufferers. If the number of pulmonary TB sufferers is large enough, it will also have an impact on the quality and competitiveness of the nation. Moreover, pulmonary TB mainly attacks the productive age group 25-54 years which is also a workforce. Therefore, the discovery and treatment of pulmonary TB services in Indonesia must be endeavored to reach the entire community towards the realization of a TB-free Indonesia.

From the Indonesian Ministry of Health data as of June 2016, it is known that the proportion of confirmed bacteriological pulmonary TB patients among all pulmonary TB patients recorded / treated in Indonesia has not reached the expected target of at least 70 percent. This indicates that the diagnosis does not give priority to finding infectious patients in Indonesia. In addition, the Case Notification Rate (CNR) which is a number that shows the number of new patients found and recorded among 100,000 population in a certain area) bacteriological confirmed pulmonary TB in 2015 in Indonesia was 74 per 100,000 population, decreased compared to 2014 which amounted to 77 per 100,000 population. While the notification rate for all TB cases in 2015 was 130 per 100,000 population, increasing compared to 2014, which was 129 per 100,000 population (Ministry of Health, Republic of Indonesia, 2016). 
Various program implementations have been carried out by several countries, especially developing countries, including Indonesia, to tackle pulmonary TB. One of the efforts undertaken by the Indonesian government is to implement the DOTS (Directly Observed Treatment Shortcourse) strategy recommended by WHO (World Health Organization) since 1995 by expanding work areas in new strategies including community participation and NonGovernment Organizations (NGOs) in TB Care, advocacy, communication, and social mobilization (Advocacy, Communication, and Social Mobilization / ACSM), as well as improving the management of MDR-TB and TB / HIV are part of the DOTS strategy (WHO, 2007). DOTS is indeed a comprehensive step to tackle pulmonary TB, but DOTS can never be successful if only done by the government itself.

In South Tapanuli District, the results of tracing documentation related to pulmonary TB disease indicate that prevention of this disease did not reach a significant target. The cure rate (success rate) in 2015 was 83 percent and in 2016 it was 91 percent (Regional Health Office of South Tapanuli Regency, 2017). Based on these data it can be assumed that there are problems in the prevention of pulmonary TB in South Tapanuli Regency. These problems can be seen from the totality of performance achievements in the prevention of pulmonary TB in carrying out programs in the community. When it was confirmed to the relevant institution, namely the South Tapanuli Regency Health Office, it was discovered that the pulmonary TB control program had undertaken several activities recommended by the government. But in reality it was recognized that the implementation of program activities did not receive much response from the community. This is related to hereditary perceptions and habits and the lack of public knowledge that the pulmonary TB disease suffered is a very dangerous health.

Regarding behavior, factors that can affect the health status of the community are inseparable from the culture and habits of the family and the daily environment of the community (Notoatmojo, 2003). Cultural values are concepts about something that is in the mind of most of the people they consider valuable, valuable, and important in life so that it can function as a guide that gives direction and orientation to the lives of the citizens (Koentjaraningrat, 2009). Implementation of strategies to achieve the achievement of pulmonary TB control programs in their own regions must be able to create a process of reshuffle and rebuild the social structure of the community, especially rural communities. But in general, the greater goal is to improve the degree of public health independently.

Community-based tuberculosis control program is a form of community participation in tuberculosis control. Cadre activeness in the Community TB Care program is the spearhead in the field. In mobilizing the community to be independent in the prevention of pulmonary TB, there must be a local figure who can be a mass attractor. Pulmonary TB prevention in Indonesia in addition to involving government partners in the National TB control program, NonGovernmental Organizations and Community Organizations can be involved in the control of Pulmonary TB (WHO, 2016).

The problem of the high number of sufferers and the low rate of treatment of pulmonary TB in South Tapanuli Regency is inseparable from the daily socio-cultural practices of the community. In general, people in South Tapanuli Regency still adhere to a culture that is hereditary in terms of treatment or health programs that are applied in daily life, including in this case the treatment of TB. TB is often considered a disease of witchcraft, poisons, witchcraft, curses and even hereditary diseases. Treatment program activities in the affected community have not been carried out optimally. Sufferers also appear to be ignorant of the effects of incomplete treatment concepts. Changes in behavior in the community in breaking 
the chain of transmission of the disease also still do not support this program. Meanwhile the prevention program carried out by the relevant agencies to reduce the number of new pulmonary TB patients also appears to have not been implemented. Implementation of the program according to the community does not involve the community and community leaders who are considered sufficient to contribute to helping the achievement of the program. In fact, if seen from the condition of this area, it still adheres to a fairly strong understanding of the figures in the community.

Situation analysis of the problem faced is that there is still no serious attention from the community for the prevention of pulmonary TB programs. In addition, other risk factors are also still high against pulmonary TB transmission such as the condition of rural communities who still do not understand the rapid transmission of this disease, as well as drug resistance due to improper treatment. Gradually, the local government has implemented a pulmonary TB control program according to the national program and carried out comprehensively but not sufficiently to reduce the prevalence of pulmonary TB.

The results of preliminary interviews conducted with the community in the treatment of TB showed that people prefer shaman (datu) to treat TB with the reason that shamans are better known and trusted by families as people who have expertise, are hereditary experienced and are considered capable of treating all kinds of diseases. This is consistent with the opinion that community behavior is closely related to culture and habits supported by social, geographic and demographic factors (Mubarak, 2009).

The structure of community life in South Tapanuli Regency adheres to the culture with the Dalian Na Tolu system (three stoves), namely kahanggi, boru children, and mora. Based on this, a person is not permitted to make a decision if there is a problem in the family, including in the field of health and treatment of diseases, meaning that each problem must be decided based on the results of a family consultation (marpokat). Treatment efforts for sick family members must involve family, relatives or religious leaders as well as community leaders who are considered as the decision makers in the community environment.

\section{Methodology}

\subsection{Research design and informants}

Qualitative research was conducted through focus group discussions (FGD) and in-depth interviews conducted in South Tapanuli District, North Sumatra Province, Indonesia. In general, the people of South Tapanuli Regency still uphold their traditional culture (Angkola, Mandailing, and Padanglawas with the philosophy of Dalihan $\mathrm{Na}$ Tolu) although there are several parts of the region that are influenced by outside cultures, such as the North which is influenced by Toba culture and the Western part which is influenced by Coastal culture. The Central part of South Tapanuli district is an area where people are more traditionally bound to the Angkola culture, the southern part to the Mandailing culture, and the eastern part to the Padanglawas culture (Tinggibarani Perkasa Alam, Ch. Sutan, 1984). For the purpose of this study, one sub-district was chosen from the five sections where the Batang Angkola sub-district represented the Central section, the Batang Toru sub-district represented the northern part, Tantom Angkola sub-district represented the southern part, Aek Bilah sub-district represented the eastern part, and Muara Batang Toru sub-district represented the western.

From the five selected districts, informants were determined as sources of data by taking into account three criteria, namely: (1) socioeconomic status; (2) community / religious / adat 
leaders; or (3) government health workers. To determine which environments are in the Upper or Lower Socio-Economic categories in each sub-district, an employee of the Department of Public Housing and the South Tapanuli Regional Settlement Area is asked to identify them. After the environment is determined, the name of the neighborhood head is identified, and then the neighborhood head is asked to provide the names of informants that are in accordance with research needs. The informant who represents the community must meet the criteria of settling in a defined environment, where the informant from the Sosek environment. Upper SocioEconomic is a response that has at least one motorcycle with reference to the criteria of Sitorus (2000). Government health workers are represented by the head of the and health workers from the South Tapanuli District Health Office. Thus, through a purposive technique with the considerations outlined above, in this study 27 informants were represented representing the community and 20 informants representing the health system consisting of 10 heads of health centers and 10 government health workers.

Data on public health perceptions related to pulmonary TB were collected by following the procedure of carrying out home visits as regulated in the Republic of Indonesia Health Regulation No. 39 of 2016 concerning Guidelines for Implementing a Healthy Indonesia Program with a Family Approach. The data analysis technique used to analyze qualitative data is content analysis proposed by Graneheim and Lundman (2004). This technique focuses on the FGD manifest content and interviews as a comparison between the Upper Sosek and Lower Sosek groups. Before collecting data the researchers submitted a letter to the research ethics committee of the University of North Sumatra. After going through several improvements and refinements to the questionnaire, the Ethics Committee team stated that the research carried out had met the ethical norms so that it was feasible to proceed.

\subsection{Data Analysis}

The technique of data analysis used to analyze qualitative data is content analysis proposed by Graneheim and Lundman (2004). This technique focuses on the FGD manifest content and interviews as a comparison between the Upper Sosek and Lower Sosek groups.

\section{Discussion}

Through content analysis of the results of the FGD and in-depth interviews related to public perceptions of pulmonary TB summarized eight categories of statements that most often appear, namely: (1) Pulmonary TB is a dangerous disease; (2) causes of pulmonary TB disease; (3) stigma related to pulmonary TB; (4) pulmonary TB treatment; (5) prevention of pulmonary TB; (6) information sources; (7) the role of community / religious / leaders culture; and (8) community action patterns. As explained in the previous section, these eight categories are grouped into three domain structures which are the main aspects of the interview guide used, namely: (1) people's perception of pulmonary TB disease; (2) how to prevent pulmonary TB; and (3) health promotion strategies. The theme of deliberation, consensus, cooperation, and harmony that is identical to Dalihan $\mathrm{Na}$ Tolu's philosophy emerged as a comprehensive perception of all informants about knowledge, attitudes, and actions towards pulmonary TB disease (Table 1). 
Table 1. Themes, domains, categories and sub-categories of Upper and Lower Social group perceptions of pulmonary TB

\begin{tabular}{|c|c|c|c|c|c|c|c|c|}
\hline Theme & \multicolumn{8}{|c|}{ Deliberation, consensus, cooperation and harmony (Dalihan Na Tolu) } \\
\hline Domain & $\begin{array}{l}\text { Public pe } \\
\text { TB disea }\end{array}$ & $e^{\text {ception of pu }}$ & monary & $\begin{array}{l}\text { How to } \\
\text { disease }\end{array}$ & al with pulm & nary TB & $\begin{array}{l}\text { Health inter } \\
\text { strategy }\end{array}$ & ention \\
\hline Category & $\begin{array}{l}\text { Pulmon } \\
\text { ary TB } \\
\text { disease } \\
\text { is a } \\
\text { danger } \\
\text { ous } \\
\text { disease }\end{array}$ & $\begin{array}{l}\text { Causes of } \\
\text { pulmonary } \\
\text { TB disease }\end{array}$ & $\begin{array}{l}\text { Stigma } \\
\text { related to } \\
\text { pulmo- } \\
\text { nary TB } \\
\text { disease }\end{array}$ & $\begin{array}{l}\text { Pulmon } \\
\text { ary TB } \\
\text { Treat- } \\
\text { ment }\end{array}$ & $\begin{array}{l}\text { Prevention } \\
\text { of } \\
\text { pulmonary } \\
\text { TB }\end{array}$ & $\begin{array}{l}\text { Different } \\
\text { informati } \\
\text { on search } \\
\text { patterns }\end{array}$ & $\begin{array}{l}\text { The role of } \\
\text { community } \\
\text { / religious / } \\
\text { adat } \\
\text { leaders }\end{array}$ & $\begin{array}{l}\text { Pattern } \\
\text { of } \\
\text { commu } \\
\text { nity } \\
\text { action }\end{array}$ \\
\hline $\begin{array}{l}\text { Top } \\
\text { Social } \\
\text { sub- } \\
\text { category }\end{array}$ & $\begin{array}{l}\text { Pulmon } \\
\text { ary TB } \\
\text { causes } \\
\text { death } \\
\end{array}$ & $\begin{array}{l}\text { Natural } \\
\text { mechanism }\end{array}$ & $\begin{array}{l}\text { There is } \\
\text { social } \\
\text { discrimi- } \\
\text { nation }\end{array}$ & $\begin{array}{l}\text { Go to a } \\
\text { shaman }\end{array}$ & $\begin{array}{l}\text { Unhealthy } \\
\text { lifestyle }\end{array}$ & $\begin{array}{l}\text { Diverse } \\
\text { informati } \\
\text { on } \\
\text { choices }\end{array}$ & $\begin{array}{l}\text { Passive } \\
\text { role }\end{array}$ & $\begin{array}{l}\text { Indi- } \\
\text { vidual } \\
\text { action }\end{array}$ \\
\hline $\begin{array}{l}\text { Top } \\
\text { Social } \\
\text { sub- } \\
\text { category }\end{array}$ & $\begin{array}{l}\text { Pulmon } \\
\text { ary TB } \\
\text { causes } \\
\text { death }\end{array}$ & $\begin{array}{l}\text { Mecha- } \\
\text { nism of } \\
\text { destiny }\end{array}$ & $\begin{array}{l}\text { There is } \\
\text { no social } \\
\text { discrimin } \\
\text { ation }\end{array}$ & $\begin{array}{l}\text { Visit } \\
\text { the } \\
\text { DOTS } \\
\text { treat- } \\
\text { ment } \\
\text { center }\end{array}$ & $\begin{array}{l}\text { Healthy } \\
\text { lifestyles }\end{array}$ & $\begin{array}{l}\text { Limited } \\
\text { choice of } \\
\text { infor- } \\
\text { mation }\end{array}$ & Active role & $\begin{array}{l}\text { Collec- } \\
\text { tive } \\
\text { action }\end{array}$ \\
\hline
\end{tabular}

\subsection{Pulmonary TB is a dangerous disease}

Almost all participants had heard of pulmonary TB, but the term "pulmonary TB" sounded unfamiliar to them. Among ordinary people, pulmonary TB is often called "TB". Pulmonary TB is considered as one of the dangerous diseases. This perception is similar for both the Upper and Lower Socioeconomic status groups. They stated that pulmonary TB disease could result in death.

"Yes, I've heard of tuberculosis. That's a dangerous disease. He said indeed people could die because of tuberculosis. I don't know why, but many people died because of tuberculosis. "(Female participant from the Lower Sosek group).

Generally both groups of informants said that coughing was a symptom of pulmonary TB and among those who were aware of coughing as a symptom of pulmonary TB, several people from the Upper Sosek group stated specifically that a cough that was more than three weeks or coughing out blood was a symptom of pulmonary TB. Only a small proportion stated that fever, fatigue, weight loss, loss of appetite, shortness of breath, and chest pain are also symptoms of pulmonary TB. However, there were several informants from the Lower Sosek group who said that coughing was not a serious symptom because their daily activities were not interrupted only because of coughing, and coughing was usually caused by colds and could stop when the body was massaged or taking herbal medicine. This misunderstanding can lead to undue treatment and fatal consequences. This situation also confirms the community's need for further health education. 
"If it's been a month the cough doesn't stop, it's definitely not normal anymore. Although there was no bleeding from the cough. If it's like that, it's good to see a doctor. "(Male participant from the Upper Sosek group).

"Some say that the cold. Just stick it, or drink goat's milk, he said. He said he had also coughed for months, then continued to drink goat's milk, soon after that healed him. "(Male participant from the Lower Sosek group).

Participants in the Upper Sosek group said that pulmonary TB was diagnosed by a medical examination by a doctor, laboratory examination of sputum, chest X-ray, blood test, and examination of fluid taken from a lump. Nearly a quarter of the lower Sosek group informants did not know about sputum testing as a diagnostic modality and were completely unaware of the pulmonary TB diagnostic method.

"Yes, pulmonary TB cannot be immediately convicted, first examine sputum, blood test. I think there are many more tests. "(Male participant from the Upper Sosek group).

"I don't know, as far as I know, when I cough, it doesn't heal, it's TB. Do you need to check phlegm?"(Female participant from the Lower Sosek group).

Both the Upper and Lower Sosek groups agreed to say that TB is a contagious disease and nearly half knew that pulmonary TB can be transmitted through saliva, breathing, eating utensils, blood, and sharing everyday items. Only a few informants did not know about the transmission of pulmonary TB.

"Contagious. So don't go near it, as soon as he coughs, goes into your nose, yes he doesn't. Drinking from a bottle of drinking even if he could do not have to. Even sputum can sputum with us. "(Male participant from the Upper Sosek group).

\subsection{Causes of pulmonary TB disease}

The Upper Sosek Group differed from the Lower Sosek group regarding the causes of pulmonary TB disease. The Upper Sosek Participants said that the cause besides direct contact with patients with pulmonary TB was an unhealthy lifestyle, such as smoking. Male participants from Upper Sosek admit that smoking is unhealthy, but they argue that smoking is needed to optimize their work, and to avoid the negative effects of smoking, they balance it with exercise and nutritious food.

"What kind of tuberculosis does not get, exercise has never been, strong smoking, staying up even the strong. What's not important is what he does. But I guess smoking is important too, especially if you think hard, you need cigarettes to get inspiration. Hahaha. "(Female participant from the Upper Sosek group).

While on the other hand, participants of the Lower Sosek group stated that they did not understand the cause of pulmonary TB. They realize that they are at risk of developing pulmonary $\mathrm{TB}$, but they believe that suffering from pulmonary TB is fate. Smoking is considered not too dangerous and not a few informants from the Lower Sosek group who think that pulmonary TB disease is the result of witchcraft. 
"Previously he was healthy and looked back at me, but as I recall we returned home from a party in the next village, at night he had a high fever, coughing for a long time until he was thin. Cough medicine has been given, not cured either. I think there is a mistake in talking to him from the village people, not apologizing to him, "(male participant from Lower Sosek group).

\subsection{Stigma related to pulmonary TB disease}

The informant group with the status of Lower Sosek claimed that they felt ashamed when a family member had AIDS. Revealing family members who have pulmonary TB is a taboo behavior because this disease is considered a family disgrace. Regarding questions about social discrimination, almost all informants stated that it is difficult for girls to get married if they have pulmonary TB. Some informants even mentioned that there was a case where a husband left his wife because he was diagnosed with pulmonary TB.

"There was an incident in our village, his father's daughter was TB. When his girlfriend came to propose, there were also people who told him that the TBC's father. The man retreated, so he did not propose. "(Male participant from the Lower Sosek group).

Informants from the Upper Sosek group have a different view, where they do not witness social discrimination among pulmonary TB patients. Some of them said that there might be a misunderstanding about pulmonary TB among people living in remote areas who did not have enough knowledge about pulmonary TB.

"In our place, there has also been a similar incident, the daughter of her father used tuberculosis. The man doesn't want to. Almost didn't. But when he consulted with his family, his bones were angry because his attitude was not good. Can make people hurt. He was told to bring the bone to the woman's father for treatment. He told the man to teach the woman to continue to regularly take medicine with her father. After recovering from his father, the person was married. The disease comes from God too right? Instead of helping to treat, they are ostracized by the sick people. "(Male participant from the Upper Sosek group).

\subsection{Treatment of pulmonary TB disease}

Nearly all participants from both groups said that TB could be cured and most of the Upper Sosek group knew that the government provided free treatment through a national program. When asked about the place where treatment is available, many of them know about DOTS treatment centers such as hospitals / clinics / health center.

"Yes, now it's already in the modern era, it's not like that anymore. There is already given medicine at the health center. Free, no need to pay. In fact, even if someone meets the disease the person is told, "bring it here," he said. "(Male participant from the Upper Sosek group).

Regarding the duration of treatment, nearly half of the Upper Sosek group gave the correct response of 6-9 months. When asked about the risks that pulmonary TB sufferers will accept if they do not undergo regular or incomplete treatment until they recover, the most common 
response that arises is death. In addition, the side effects of the drug and the negative reactions felt by the body of patients with pulmonary TB shortly after they take the drug are reasons for not continuing treatment.

"People who are TB sufferers, if he stops treatment, usually it is because he feels good, healed. Even though the risk can die. "(Male participant from the Upper Sosek group). "Taking the medicine for 6 months must have made me bored, some were vomiting as many drugs as they needed to take, the body became limp and could not work, and the eyes ran away. Usually that is the reason why people with TB stop taking medicine. "(Female participant from the Upper Sosek group).

Different with the Upper Sosek group, most Lower Sosek groups do not know the free medical treatment provided by the government. Regarding the assumption that most of them believe that pulmonary TB is a destiny or a disease caused by "magic", they come to "datu" or "shaman" to get spiritual healing.

"Do you have free medical treatment? How could it be. There is nothing free in this world. "(Female participant from the Lower Sosek group).

"If it is predestined to be sick, even in a healthy bed can die. Right? "(Male participant from the Lower Sosek group).

"If you haven't recovered for months, you have taken medicine, or even cured, isn't that odd. Try asking a smart person first. I don't know about us, it could be the pulp that was made up by people. "(Female participant from the Lower Socio-Economic group).

\subsection{Prevention of pulmonary TB disease}

When asked about the prevention of pulmonary TB, the majority of the Upper Sosek group stated that pulmonary TB can be prevented by maintaining cough hygiene (wearing masks), BCG immunization, isolating sufferers, not sharing daily equipment with sufferers, not smoking, exercising, and consumption nutritional food.

"If you have been immunized as a child, you will not be afraid of you. Even if it does, it's not severe. The immunization place does not have to wait for the Maternal and Child Health Services to arrive, just go straight to the clinic. "(Female participant from the Upper Sosek group).

"People who use TB are best not to have to take part in a gathering, at home, even if they come out, wear a mask. Just treat it first, don't break up. Drink it even with the same cup. It is good to say, so as not to offend him. "(Male participant from the Upper Sosek group).

"Just stop smoking, spend money, invite disease. Eat lots of vegetables, exercise. If the body is healthy, fit, the disease is not easy to come. "(Female participant from the Upper Sosek group).

Generally informants from the Lower Sosek group consider that unhealthy habits or lifestyles such as smoking are not too dangerous and their work as farmers and unskilled laborers is considered as physical activity which is equivalent to sports. 
"People, if you have a lot of mind, usually smoke. Smoking helps relieve stress. Until now, look at it, there are still many more people who smoke longevity. Hahaha. "(Male participant from the Lower Sosek group).

"Sports are for the rich, they just sit in the office. Our kind, for most of the day the body is forced to move. The sport is also that. "(Male participant from the Lower Sosek group).

\subsection{Dalihan Na Tolu}

The themes of deliberation, consensus, cooperation and harmony, which are identical with the Dalihan Na Tolu philosophy, appear in all categories of Upper and Lower Socio-Economic groups. The kinship system in South Tapanuli community is analogous to "three stoves" which are the same distance and under the same heavy pressure so that they support the cooking utensils above. Cooking tools are defined as a burden of obligation or work done jointly called horja. All elements, namely mora (the giver of the wife), kahanggi (the same mate), and the son of boru (the taking of the wife), take part in horja which can only be done after reaching consensus at the time of marpokat / martahi (deliberation). Deliberations and consensus were emphasized by participants from both the Upper and Lower Sosek groups in each decision making to be done together. Decision making in deliberations related to health issues will be followed by treatment and disease prevention measures jointly by all elements of the community.

Regarding public perception of pulmonary TB disease, both the Upper and Lower Sosek groups believe that the environment and unhealthy lifestyles are the cause of the disease. Informants from the Upper Sosek group acknowledged that an unhealthy environment and lifestyle could result in pulmonary TB disease, while the Lower Sosek group did not recognize it as the main cause.

"Once I came to my friend's house. His wife is my sister, because of my same age. I looked dirty at his house, lots of dust. There I reminded him of the principle in our custom: 'Baenma huta dohot banua marjalangan na so marrongit. A dirty dusty house can make you get TB. I did not hear. Now, that's right, he got TB. "(Male participant from the Upper Sosek group)

"That's right. I can't stop smoking, but if too much makes my lungs break. Ha ha ha. The money that could have been used for shopping was burned out. Ha ha ha. So in front of my bones I often hold back so that I don't look strong the next time I smoke. "(Male participant from the Upper Sosek group)

The participants also showed that the treatment and prevention of pulmonary TB can be realized through deliberation and cooperation within the family that is strengthened by harmonious kinship. In the kinship system in Dalihan $\mathrm{Na}$ Tolu, the harmony of each element (mora, kahanggi, and boru children) is seen in traditional expressions that are commonly heard among the people of South Tapanuli: "Manat sanga pe jamot marhamaranggi, elek marboru, respect for marmora", which is interpreted as: "Be careful of kahanggi, apply compassion to boru children, and always respect mora". Both the Upper and Lower Sosek groups agreed that if a family member (boru child) was suspected of having pulmonary TB disease, then the mora and kahanggi elements of the family (respected and whose advice was obeyed by the boru 
child) should be involved to provide encouragement to seek treatment immediately and together to ensure that the treatment is complete.

"We are a family, we must cooperate. We have a way to force people who don't want treatment. If, for example, my husband coughs to the point of bleeding, and doesn't want to get treatment either, I ask his friend to force him to seek treatment. His friends are especially valuable (kahanggi). If you don't want to, then I'll tell my father or my brother. That's the mora. "(Female participant from the Upper Sosek group)

Informants from both the Upper and Lower Sosek groups describe harmony in the kinship of each element not only at the family level, but also at the community level. They claim that harmony in society is built collectively.

"Public awareness depends on us too. If we consider this disease a joint problem, yes we solve it together. We who know our problem, we also can solve it. As long as you want to work together. "(Community leaders from the Lower Sosek group)

\section{Discussion}

Data from the content analysis results from FGD and in-depth interviews revealed the perception of the people of South Tapanuli Regency on Pulmonary TB disease Different patterns of action in the community perspective, in which the Upper Sosek group tends to act individually and the Lower Sosek group tends to act collectively, implying the need for a health promotion approach different.

National, which mandates health management to be carried out through community participation and empowerment, implies that the health program approach must pay attention to differences in the patterns of action of the diverse Indonesian society. But at the implementation level, the national health system offers only one common approach for all communities. Whereas the uniformity of such an approach might not be suitable for people who differ in socioeconomic and socio-cultural status. Communities in the Upper Sosek group generally act independently in the search for health information and have diverse choices for health programs so that they are able to solve health problems themselves, while people in the Lower Sosek group have limited resources and information so that they will usually be willing to take it for granted programs offered by the health system.

With the conditions described above, prevention of pulmonary TB disease cannot be expected to be successful if it is not supported by active community participation. Active community participation requires the support of the health system as stated by Laverack (2007) that the health intervention program will only be sustainable as long as there is a significant push from the health system. For this reason, in the prevention and control of pulmonary TB, the health system must overcome the erroneous assumption in the Lower Sosek community related to stigma against pulmonary TB disease and destiny as a cause of pulmonary TB disease. 


\section{References}

Blum, H. L. 1974. Planning for Health, Development and Aplication of Social Changes Theory. New York: Human Sciences Press.

Dinas Kesehatan Kabupaten Tapanuli Selatan. (2017). Profil Kesehatan Kabupaten Tapanuli Selatan. Padang Sidempuan.

Graneheim, U. H. dan Lundman, B. (2004). Qualitative content analysis on nursing research: concepts, procedures and measures to achieve trustworthiness. Nurse Education Today, 24:105 - 112.

Green L. W. \& Kreuter M. W. (2005). Health Program Planning An Educational And Ecological Approach: Fourth Edition: Mc-Graw-Hill, 1121 Avenue of The Americas. New York.

Kementrian Kesehatan RI. (2016). Profil Kesehatan Indonesia Tahun 2015. Jakarta.

Koentjaraningrat. (2009). Pengantar Ilmu Antropologi. Jakarta: Rineka Cipta

Laverack, G. (2007). Health promotion practice. Berkshire, England: Open University Press.

Mubarak, W. (2009). Sosiologi untuk Keperawatan: Pengantar dan Teori. Jakarta: Salemba Medika.

Notoatmojo, S. (1993). Pengantar Pendidikan Kesehatan dan Perilaku Kesehatan. Yogyakarta: Andi Offset.

Sitorus. (2000). Berkenalan dengan Sosiologi. Jakarta: Erlangga.

Tinggibarani Perkasa Alam, Ch. Sutan. (1984). Seni budaya tradisional daerah Tapanuli Selatan, suku Batak Angkola, Padanglawas, Mandailing, dan Pesisir: pelajaran adat Tapanuli Selatan. Padangsidempuan.

WHO. (2007). Advocacy, communication and social mobilization (ACSM) for tuberculosis control: a handbook for country programmes. World Health Organization 20 Avenue Appia, 1211-Geneva-27, Switzerland.

WHO. (2016). Global Tuberculosis Report 2012. World Health Organization 20 Avenue Appia, 1211-Geneva-27, Switzerland. 